\title{
Experimenting with Law: Brecht on Copyright
}

\author{
Jose Bellido ${ }^{1}$ (D) \\ Published online: 31 January 2020 \\ (c) The Author(s) 2020
}

\begin{abstract}
Can one reject copyright law and be a qualified observer of its dispositives? This question was taken up by Bertolt Brecht in an intriguing essay concerning the litigation surrounding the film adaptation of The Threepenny Opera (1928). Brecht here develops an experimental observation around the nature of film adaptation and cultural production in copyright. While an experimental approach to law was in itself a subversive gesture, the specific legal process enabled him to expose the paradoxical ways in which the copyright system worked.
\end{abstract}

Keywords Brecht $\cdot$ Copyright $\cdot$ Experimental knowledge $\cdot$ Film $\cdot$ History of copyright law $\cdot$ Law $\cdot$ Mass media

I have always needed the spur of contradiction (Bertolt Brecht)

\section{Introduction}

Copyright scholars often trace a revival of history writing in their discipline to the late 1960s (Deazley et al. 2010, p. 2). Although the study of copyright history dates back significantly further, a new focus on historical writing has emerged over the last five decades as part of an attempt to understand and delineate copyright's historical peculiarities. Much of this revival is rooted into the publication and reception of Michel Foucault's essay 'Qu'est-ce qu'un auteur?' This opened copyright scholarship up to the perspectives of literary scholars concerned with the historicity of authorship and the intersection between law and literature (Woodmansee 1984; Rose 1988). As Bowrey notes, 'the essay had such an influence on the literary studies perspective on copyright that it seems to have become a convention respectfully to acknowledge or quote from this piece in opening paragraphs' (Bowrey 1996, p. 323). Foucault's work challenged theoretical presuppositions about authorship and thus attracted the interest of some legal scholars (Deazley et al. 2010, p. 2). Even

Jose Bellido

j.a.bellido@kent.ac.uk

1 Kent Law School, University of Kent, Canterbury, Kent CT2 7NS, UK 
when it gave rise to mutually incompatible understandings, Foucault's essay paved the way for a new scholarship sensitive to very specific ways of thinking about copyright and the contingent nature of its history. Such a trend in scholarship also brought unintended consequences; amongst other things, an excessive focus on the 'author' as the main feature of the system. It has been suggested that copyright historians became too obsessed with the 'author-function' and with the ways in which romanticism influenced its construction, at the expense of forgetting other equally essential technological underpinnings of copyright-namely, the 'work' itself (the book, the play or the film), and its circulation. Broadly speaking, this blind spot in the thematic development of copyright history is remarkable because in legal proceedings, the 'work' becomes a gravitational point around which copyright revolves. As Sherman observes, 'the work, which came into its own with the emergence of modern copyright law, occupies a pivotal (but largely unexplored) position in copyright law' (Sherman 2011, p. 120).

One book that shifted the emphasis from authorship towards other historical features of copyright, such as the distinctiveness of particular cultural productions and markets, is Bernard Edelman's Le Droit saisi par la photographie (1973). Although some cultural theorists and critical legal scholars appreciated this departure from traditional legal analysis (Gaines 1991), others argued that Edelman's book 'had little influence on the recent trajectory of copyright history as a discipline' (Kretschmer et al. 2013, p. 40). Precisely because the book stood out as an exception to the orthodox understanding of copyright in legal history and theory, copyright scholars have not paid sufficient attention to one of the main influences in Edelman's work: Bertolt Brecht's Der Dreigroschenprozeß (The Threepenny Lawsuit). At first glance, this lack of attention is nonetheless surprising. According to theatre scholars, The Threepenny Lawsuit constituted 'the most important contribution to the sociology of art and film at this point in [Brecht's] career' (Kuhn and Giles 2003, p. 63). The work underpinned some of Walter Benjamin's best-known writings (Benjamin 1935, 1936; see also Markus 2001; Wizisla 2014, p. 162), and Benjamin's work has been hugely influential in culture and art theory. Legal scholars in the United Kingdom, however, have largely failed to appreciate the influence of Brecht's essay on the scholarly discussions of copyright. Why such silence from copyright scholars around a critical text from one of the most important playwrights of the twentieth century? There are several plausible explanations. It is probable that the belated appearance of The Threepenny Lawsuit's English translation affected its reception. ${ }^{1}$ While the translation of the essay into French made it accessible to Edelman and other cultural critics in France in the 1960s, mainly those of the Cahiers du Cinéma, the full English translation was not available until 2000 (Giles 1998, p. 49). Further obstacles to its reception could also relate to Brecht's difficult assimilation into the United Kingdom, well summarised by Willett (1977, pp. 213-225). The controversies surrounding a complicated subject might have been an additional obstacle. As Walter Benjamin once wrote: 'Brecht is a difficult phenomenon' (Benjamin 1998,

\footnotetext{
1 Brecht (1970) and Silberman (2000). Although some extracts were translated by John Willett into English in 1964, the full essay was not available in English until 2000; see Brecht (1964a, pp. 47-51).
} 
p. 27). Crude, concrete and always testing the people and the circumstances around him, Brecht was an enfant terrible, a nonconformist, a dramaturg whose writing sat uneasily within conventional disciplines. Accused of being a 'plagiarist, trouble-maker, and saboteur', he took some of these labels as a compliment (Benjamin 1998, p. 27). His elusive and uncompromising character and unclassifiable writing is what makes him an interesting and unusual feature in copyright historiography. For Brecht fundamentally disagreed with the principles underpinning copyright. And yet, not only did he decide to sue a company for breach of a copyright, but he also wrote an extensive essay on the topic. While this combination made him surely unpalatable to many legal theorists, positivists and orthodox Marxists alike, it is nevertheless what contributes to the singularity of this case. How could someone like Brecht, ever reluctant to trust legal institutions, come to provide insight into the ways in which copyright worked?

\section{Rehearsing Failure}

The Threepenny Lawsuit first appeared in German in the Versuche series, which consisted of fifteen grey paperbound journals published by Kiepenheuer, who published most of Brecht's texts in the early 1930s. These texts were inscribed in a practical manner of documenting, re-writing and staging actions to adopt a stance of critical observation, a tendency itself part of Brecht's 'epical' approach not only to theatre but also to society. As the introduction to Brecht's Versuche explains:

The publication of the Versuche takes place at a moment when certain works are intended less as individual experiences (with the character of finished works) than as a means of using (transforming) certain institutes and institutions (i.e. with the character of experiments) and with the object of continually illuminating by their coherence each of the very varied operations undertaken (Willett 1977, p. 170; Benjamin 1998, p. 93).

This attempt to bring the distance of a theatrical play (and its different tools of masking and unmasking) to social institutions like law, shaped Brecht's pragmatic approach. He wrote The Threepenny Lawsuit after losing a copyright case concerning the film adaptation of his play The Threepenny Opera (1928). In contrast to other playwrights and critics of the time, Brecht embraced the new medium. He imagined the process of adaptation not as a derivative endeavour, but as a creative process that could enable him to access the means of film production. In May of 1930, Brecht and Kurt Weill, the composer of the film's score, signed a contract with Nero-Film AG to produce a film version of the play. ${ }^{2}$ Nero-Film, in turn, partnered with Tobis Klangfilm, a film company in partnership with Warner Brothers, to

\footnotetext{
2 The contract of 21 May 1930 has the reference number BBA 576/14-18 (=original, BBA 82/2-6+1= copy); Bertolt-Brecht-Archiv.
} 
produce the film. ${ }^{3}$ Although Nero-Film AG agreed to Brecht's demand for a 'right to have a say' in the development of the script, technically referred to as a 'consultation right' (Mitbestimmungsrecht), Brecht and Weill soon found themselves in conflict with the company over how to adapt the play to film (Elsaesser 1990, p. 104).

The resulting litigation concerned the link between property and contract often entwined in cinematographic adaptations. Disputes over adaptations offer insights into the real and personal themes embedded in negotiating copyright. In Brecht's dispute, the falling out between the parties elicited diverging views about how the juridical forms in which authorship and collaboration, capital and labour, technology and transformation, and ownership and appropriation, were practically arranged. When a conflict like this arises, it is possible to see the different images that these operations around copyright could potentially presuppose. The controversy between Brecht and the film company emerged precisely because of their conflicting views on planning and organising the production of the film. Brecht understood the deployment of the contract and his 'right to have a say' in a very specific manner. Instead of being a straight adaptation, he considered that the play had to be substantially altered in order to adapt it to the new medium. His changes not only affected the setting, but also emphasised the political and ideological character of the medium, a modification that would have exposed the film to censorship. ${ }^{4}$ Furthermore, Brecht's collectivist work ethos and the difficult meetings between the film executives and Brecht to specify the legal obligations irritated the production company. For instance, he only met the agreed deadline by communicating some of his ideas (orally) to Leo Lania, the scriptwriter. And he did so in a way that put the production timeline at risk. Unhappy with the project falling behind schedule and afraid of losing control over the means of production, the film company asked Brecht to step aside. It went ahead hiring other collaborators, such as Béla Balázs and Ladislaus Vajda, to support G.W. Pabst's cinematographic adaptation of the play (Petrie 2004, pp. 2-27, 4; also see Heidt 2014, pp. 178-196). Brecht criticised Pabst's film while it was still being made, labelling it 'an intolerable adulteration of the ideological and stylistic content of his play' (Eisner 1973, p. 343). Similarly, Weill lamented the introduction of unauthorised musical episodes into the film and denounced Pabst's adaptation as an 'operetta film', and mere 'kitsch' (Weill to Universal Edition, 6 August 1930 in Farneth et al. 1999, p. 112). And he was shocked by the overall attitude of the NeroFilm executives as 'being in a constant state of confrontation with us' (Weill to Universal Edition, 6 August 1930 in Farneth et al. 1999, p. 112). He vividly referred to their experience with film executives as 'one only thought to be possible in Wild West novels' (Morley 1998, p. 14).

Although Brecht and Weill were already busy with other theatrical projects, such as the rehearsals for Aufstieg und Fall der Stadt Mahagonny, they decided to sue

\footnotetext{
3 'The Warner Brothers involvement was supposed to generate an English-language version alongside the German and French', Rayns (2007).

4 In fact, the film company (Nero-Film AG) argued that they could not allow the 'decidedly political tendency' Brecht was going to give to the film because they were a 'politically neutral enterprise' concerned about censorship (Jelavich 2006, p. 199). In fact, Pabst's movie was subject to censorship; see 'Censorship Report' 6/5/1931; Beggar's Opera (1931) 'Three Penny Opera'; Folder 2703A; Warner Bros. Archives; USC School of Cinematic Arts.
} 
the film company and sought an injunction to prevent the film's production. Brecht argued that he was prevented from exercising both his contractual rights and his copyright, while Weill argued that his music was changed without his authorisation. The main issue in the ensuing legal proceedings turned out to be the nature of Brecht and Weill's involvement and behaviour during the production process. Although Brecht and Weill instituted the legal proceedings, all parties, including Nero-Film, felt that the others had failed to fulfil contractual obligations and expectations. The controversy highlighted tensions between the litigants' divergent perceptions of property and propriety in their arrangements for collaboration. Although the film company objected to the 'political tendency' of Brecht's version (Parker 2014, p. 283), the court attempted to exclude from its domain questions of aesthetics, politics, and other matters perceived to be subjective in nature..$^{5}$ As Steve Giles has observed, the court instead focused narrowly on contractual issues and on Brecht and Weill's right to object to changes to their work-what might be described today as a moral rights claim in disguise (Giles 1997, pp. 21-27). While that is obviously a retrospective take, it is still worthwhile recalling some procedural features of the trial held in Berlin. The court went to see the performance of the play but naturally could not watch a film that had yet to be made. Moreover, Brecht himself became interested in the hearing, and attended the proceedings in person until angered by the insinuations of the lawyer for the defendant at which he 'swept out of the courthouse leaving his lawyers to carry on with the proceedings' (Eisner 1973, p. 345). Despite, or because of, Brecht's recalcitrant attitude, it is not a surprise that his case was dismissed, even though Weill's claim was upheld. ${ }^{6}$ Brecht lost the case, in other words, due to his failure to engage constructively with the film company. The court's decision hinged on their interpretation of whether or not Brecht had acted in good faith. For Brecht, the technical source of this 'discovery of fact' was probably interesting. According to the film company, his contractual performance was characterised by a series of intolerable delays, recalcitrant behaviour and organisational problems. Brecht's decision to take a holiday in the south of France while these collaborative problems flared up did not help his cause (Katz 2015, p. 304). Such conduct against capitalist expediency seems to have persuaded the judge to dismiss Brecht's claim. Furthermore, the court took heed of his reluctance to hand over a written document of his screenplay to Nero-Film - another example of 'bad faith' that brought into question the ownership of the very property upon which the collaboration for the film adaptation was constituted. Brecht was not one to accept being framed in those terms, particularly when this finding was precisely what connected copyright to the attempt to construct a 'reliable' marketplace. This could explain why he lost the litigation and was ordered to pay costs.

\footnotetext{
5 'The verdict was ultimately decided without paying much attention to Brecht's heartfelt proclamations about the relationship between art and commerce', Katz (2015, p. 310).

${ }^{6}$ A few years later, Weill saw the film and considered that it feels quite old-fashioned, which proves that it never was any good in the first place'; Weill to Lenya, 29 May 1937, in Symonette and Kowalke (1997, pp. 242-243).
} 


\section{From Conflicts to Paradoxes}

Although triggered by a copyright case, The Threepenny Lawsuit bears an odd relationship to the judgment. The disparity in scale between the essay and the judgment is striking. While the latter was brief and unexceptional, Brecht's account was lengthy and provocative, over twenty pages longer than the decision (Dommann 2015). In his essay, Brecht brought together the case and its many underlying aspects: contracts, press reports, lawyers, legal maxims, etc. This eclectic approach understood the legal process as a question of gathering sources rather than of resolving a dispute. Brecht emphasised the epistemic potential of his failure and described the lawsuit as a 'sociological experiment, organised for the purpose of seeing certain ideas at work' (Brecht 2000a, p. 160). The aim of instigating the trial, Brecht said, was 'publicly to demonstrate the impossibility of collaboration with the film industry, even given contractual protection. This aim was achieved-it was achieved when I lost the trial' (Hinton 1990, p. 45). Unlike so many other losing plaintiffs who write to set the record straight, Brecht did not just try to convince others that the court failed to recognise his rights. On the contrary, his main concern was to observe the contradictions of law, starting with his own contradictory legal position. Although he did not wish to recognise the court's jurisdiction, he was nevertheless forced to seek his rights in court-rights only available to him as rights to private property (Brecht 2000a, p. 157). Here we can see how Brecht was aware that the legal subject does not simply exist in and of itself but is instead produced by law. In other words, the legal operation produces the subject. Treating the court case as raw material to ponder, Brecht concluded that the litigation and defeat were ultimately worth the trouble because they afforded a 'new insight into the structure of cultural production in contemporary capitalist society' (Parker 2014, p. 283). Brecht's insight enabled him to overcome one of the usual problems of writing about law. Rather than criticising the law from the outside, Brecht's involvement in the legal process enabled him to take an internal point of view. As he noted, 'only the subject who participates and who is involved is capable of knowing here' (Brecht 2000a, p. 198). Although this 'double gesture' was later criticised by some commentators, there was no better way to irritate the system from 'within' than by citing himself in a case in order to expose and highlight the contradictions of law under capitalism. In fact, legal proceedings presented Brecht with an opportunity to shift from the typical static reflection on the case to the dynamic observation of the legal process in flux. Shaping the perspective of the essay largely through third person narrators (one of them being himself), Brecht blurred the distinction between author and character, moving from the legal case to the case of law. Such manoeuvring allowed him to capture the ways in which copyright law and doctrine became an undertaking geared towards production. In exploring this, Brecht noted not only the 'creative' interpretation of the law by the judge, but also the constitutive role of the discursive practices of the public sphere in the litigation (Rokem 2014, p. 83). Ultimately, Brecht's experimental demonstration challenged the presuppositions of juridical rationality.

Brecht's essay drew attention to law's mundane practices. Money, he noted, was intertwined with law. Although scholars tend to elide the financial aspect 
of legal proceedings, Brecht identified the cost of litigation as an aspect that anchored the case. This led him to consider that access to the law was from the outset simultaneously transformed and mediated by money. Law had become a commodity, and litigants experienced pleadings as a financial burden. Similarly, follow-up attempts to lodge an appeal also had a price tag which, according to him, was unreasonable. The economic burden that court cases inflicted upon litigants converted capital into an agent in the dispute. In other words, the law had been converted into a system in which lawsuits became objects of exchange. It was not just that money constituted a barrier; the most significant feature of this connection between capital and litigation was that it linked law to an economic struggle; that is, that law had the ability to recast litigants as calculating subjects. Brecht summarised this point by suggesting that the copyright lawsuit demonstrated 'how far the process of transforming intellectual values into commodities ha[d] progressed' and cited Cicero's observation that 'the system of law costs either justice or money. For justice waits behind many doors that can only be opened with money' (Brecht 2000a, p. 144). By making explicit the fact that a procedural issue is largely a socio-economic affair, Brecht indicated that the framework of a legal case simultaneously encourages both litigation and settlement, at the expense of subordinating justice to capital. In other words, that legal cases encourage further legal cases; making law not just a remedy but a hugely successful enterprise as such. Brecht's point was not just that capital attempts to establish its hegemony on the legal process. Rather, he emphasised the relevance of capitalism as a mode of subjectivation: a particular subject is compelled to emerge when law becomes a commodity.

Money became then a cipher that enabled subjection and control before the law. The subtitle of the essay ('A Sociological Experiment') here acquires further meaning. As well as revealing a pragmatic attention to the legal process, it shows a remarkable feature of Brecht's undertaking. As Ian Hacking noted, 'it [was] in praxis and not in theory that he and his being [was] constituted' (Hacking 2002, p. 32). In a deliberate foregrounding of legal practice, Brecht subversively conceived law as a locus of experimentation. For most of us, the idea that law can be subjected to experimentation at all seems counterintuitive, almost oxymoronic. Is it possible to toy with law? Can legal proceedings be experimented with? Brecht's sociological experiment shows that it is possible to do so.

Furthermore, for Brecht, court proceedings were merely the stage, or one of many stages; the experiment went beyond the courtroom in order to show how the legal process influenced the ways the case was reported and observed. Methodologically speaking, the experiment was an intervention in the public sphere that brought to the fore a series of propositions. Brecht tested these propositions to, in effect, construct a case about his case. In other words, Brecht built his experimental case not to see if he would be deemed right (or wrong), but to make the legal machinery explicit and therefore disputable. It is tempting to compare such an experimental inquiry to a theatrical project and perceive Brecht's 'position' as staged. Not only is it possible to consider the experiment as influenced by Brecht's other theatrical practices, such as the attempt to develop his 'epic' theatre (Verfremdungseffekt) and his contemporaneous making of 'learning-plays' 
(Lehrstücke), but it is also possible to, with Frederic Jameson, link Brecht's method to André Jolles' concept of casus (case): 'the arguing back and forth, the attempt to specify, particularly thorny legal issues and matters of judgments' (Jameson 1998, p. 80).

The performative aspect of Brecht's experimental method drew the ire of contemporary critics. Siegfried Kracauer, the influential cultural critic for Frankfurter Zeitung, dismissed Brecht's essay as anecdotal, irrelevant and lacking scientific rigour (Kracauer 1932). Kracauer's hostile reaction is interesting because it revealed how unusual Brecht was in conceiving law as capable of being experimentally addressed. Kracauer accused the experiment of being parasitic and polluted by subjectivity; he argued that Brecht had consciously created the experiment and was unable to demonstrate what it claimed to demonstrate. Most importantly, Kracauer explicitly raised questions of authorship, discipline and responsibility. He accused Brecht of smuggling in citations, sloppy use of quotation marks and generally behaving like a 'thimble rigger', creating textual effects using sleight of hand techniques. Brecht was not troubled by these niceties. Rather, he anticipated such criticisms by denying any attempt to develop an objective method. His essay was guided by something other than 'objective, disinterested' perspectives in a radically antagonistic social system (Brecht 2000a, p. 149). The experiment entailed his participation. According to him, one reason for conducting the experiment was the absence of a public office looking after the interests of society as a whole. As a result, he decided to posit himself as an element of the contradiction itself and shift the case from a private action to a public experiment. In doing so, his own court case became less important and the experimental case concerning the legal system itself occupied centre stage (Mueller 1986, p. 21).

Those who follow the aesthetic debates of this era cannot fail to notice Kracauer's reproach to Brecht for his lack of engagement with contemporary Marxist scholarship, in particular György Lukács' History and Class Consciousness (1923). His criticism anticipated what will become a battleground for Marxist thought throughout the twentieth century: the question of the possibility of investigating and intervening in social reality. What sharply distinguished Brecht from Lukács was their different attitude towards experimentation, a distinction that also revealed their different take on society. Unlike Lukács, who rejected techniques like distancing and montage, Brecht considered them crucial devices to access, perceive and construct 'reality' as an active process. For instance, Brecht noted that 'reality was to be constructed in the lawsuit' (Brecht 2000a, p. 158). Such a realist-constructivist controversy is still relevant today as contemporary discussions and thought experiments about copyright law and the possibility of empirical evidence have intensified recently (Towse and Watt 2008; Buccafusco and Heald 2013). The transformation of copyright scholarship into a policy-orientated outlet, the rise of the audit society and the impulse to produce impact-driven scenarios are among the factors that have contributed to the resurgence of this debate. While experiments and empirical evidence have plagued contemporary copyright scholarship, these modes of analysis do not frequently reveal their conditions of possibility to access and construct that reality. They do not usually accept or reveal the paradoxical nature of legal knowledge. Nor do they often consider their own artificial construction of reality. The clearer 
their focus on empirical data, the more difficult it becomes for copyright scholars to understand the idea of law and reality that emerges from these experiments.

\section{Commodity, Law}

Brecht's analysis moved beyond the litigation itself to unpack questions about the relationships between art, law and commerce. His experimental encounter with the law intertwined copyright jurisprudence with processes of artistic and cultural commodification, thereby shifting the focus of aesthetic activity to production rather than creation-a topic later developed by Walter Benjamin. In doing so, Brecht attained insight into the contradictions surrounding film copyright in the early twentieth century. Contrary to orthodox understandings of copyright doctrine-which tended to romanticise individual artistic autonomy-Brecht considered art (and law) as integrated into market processes. What better example of this than the decision in his case? The Threepenny Lawsuit was nothing if not an epistemic object, a record teasing out the paradoxes created between theory and practice: how copyright law embraced economic relations capable of overriding doctrinal conventions. That copyright jurisprudence encountered its limits in the case became an opportunity for the law to value capital over labour. This was a contingent effect of copyright law confronting film as a new medium, but it was also evidence of how those contradictions were central to the constitution of copyright. Given Brecht's interest in how copyright jurisprudence reacted to film, Brecht's views have affinities with contemporary scholarly attempts to define copyright as a 'creature of technology' (Sherman and Wiseman 2012). However, the strategy underlying Brecht's experiment went further. It also exposed salient features of the cultural industry at the time. Brecht described the cultural industry as a factory for which authors offered their 'naked labour' (Brecht 2000a, p. 162), like Henry Ford's assembly lines. This provocative analogy equated manual workers with intellectual workers. Although there are problems translating this image to a post-industrial digital world, Brecht's comparison enables us to draw parallels between the contemporary decline of the working class and the crisis of authorship in law. Brecht's experimental treatment of the law was remarkable not only because it criticised the romantic notion of authorship underpinning copyright, but also because it questioned the commodity status of creative works. In the case of film, copyright was entangled in an industrial process in which the creative work reached the market as a total and closed entity. According to Brecht, the rights of the author were allowed and welcome in this system as far as they could be put at the service of capitalist production (Brecht 2000a, p. 188). In other words, Brecht concluded that the enforcement of his contractual rights was not possible, precisely because the actual success of those rights would have disrupted the normal functioning of the system. Here, Brecht highlighted the flexibility of copyright law when dealing with authors' rights. Such elasticity, and the judicial ability to combine contradictory qualities, allowed copyright to satisfy the demand of capital in an economic manner. If the author challenged or interfered with the flow of commodities, Brecht noted, trouble was bound to follow. More specifically, the author would be limited in his choices and would quickly come to be considered 
a 'Shylock' (Brecht 2000a, p. 191), and he would face a similar predicament: would he demand his pound of flesh?

While this move could be seen as a criticism of the capitalist system à la Adorno, Brecht did not merely echo the familiar jeremiad. His sociological experiment staged a moment in which copyright generated normative standards for developing a narrative that rationalised and favoured capital. Brecht sought to reveal the process by which the proceedings reformulated and rewrote copyright law. For Brecht, the litigation did not only show that law was associated with capitalism, it significantly helped to blur the familiar distinction between art and commerce embedded in copyright. Deliberately breaking the idealist illusion of art derived from genius, Brecht did not look back nostalgically for a notion of art already gone for good. Neither was his approach a disenchanted diatribe against artists who prostituted themselves to commerce. Brecht was not appalled or ashamed to discover that art is often transformed into a commodity. The importance of his experiment lay in how it allowed authors to see how commodification was accomplished through law.

Through his courtroom encounter with the question of property, Brecht sought to highlight the possibility of a strategy for artists to take control of the means of production. Brecht drew attention to how cultural commodities circulated, as well as to how contractual analogies in copyright might confuse the ways in which specific commodities were constituted. Films were singular commodities and the film production contract was 'a specially conceived contract that must be appreciated on its own merits' (Brecht 2000a, p. 186). Although it shared features with publishing contracts, such as an emphasis on textuality, what made the film commodity unique was that the text was 'to be transformed into actions and performance' (Brecht 2000a, p. 186). Similarly, the film's ability to be reproduced and circulated widely meant that film contracts differed considerably from theatrical contracts attached to specific stage performances. Films' circulation and market orientation beyond the theatrical network converted them into 'mass commodities' intended for distribution around the world. The interesting detour that Brecht took when looking at publishing and theatrical contracts avoided a straight comparison to show how differently configured commodities circulated. If copyright was 'dependent upon, and, in part, the product of mechanical reproduction' (Sherman 1995, p. 34), the sociological experiment was remarkable because it specifically exposed films as commodities shaped by and shaping different commercial circuits dependent on diverse ways of reproducing them. By drawing attention to the point that the circulation of capital was, after all, a form of communication (Brecht 2000a, p. 169), Brecht challenged the reader to consider culture and communication as a question of consumption. This is interesting because it reveals a shift away from orthodox Marxist categories of labour and class and towards other media frames such as communication, consumption and circulation (Mueller 1989).

Even though the film medium's ability to circulate widely as commodities made them increasingly complex products, Brecht saw the emergence of cinema as a distinctive cultural-technical form through which the world would increasingly be experienced and understood. The industrialised medium of cinema, according to Brecht, inflected the world with a distinct cultural horizon by affecting how people consumed literature and art. As a result, 'the film viewer read stories differently. But 
the person who writes stories [was] for his part also a film viewer' (Brecht 2000a, p. 161). The porous boundaries between cinema and literature, for instance, meant that 'the technological advance in literary production [was] irreversible' (Brecht 2000a, p. 161). In other words, cinema was about to take art and literature into the age of technical reproducibility because it had the potential 'to supersede the traditionally untechnical, anti-technical, transcendent "art" associated with religion' (Brecht 2000a, p. 162). While Brecht saw the cinema's potential to develop new ways of reading and writing as both interesting and inevitable, he argued that the most important feature of film was its technical potential for unsettling and subverting the means of production. As cinema detached literature and art from the ideal and inserted it into the technical, this historical juncture constituted a key moment for intellectual workers to intervene in the production process, and that intervention became imperative since 'the socialisation of the means of production [was] vital for art' (Brecht 1964a, p. 48). The large-scale collaboration embedded in filmmaking and the technological network assembled by the cinematic apparatus converted it at once into a place saturated by capital and a site in which creative subversion was possible. Although the hybrid character of films (as both industrial products and creative works) is still inscribed in copyright today, Brecht's insight was that this hybridity is what made film remarkable, for it exposed the entangled relations between cultural industries and copyright. In other words, the central affinity between creativity and industrialisation made films the clearest example of the relevance of copyright in the age of mechanical reproduction.

\section{Film Copyright}

Brecht found the place to experiment with law precisely through a technique that one might call 'cinematic', namely, the practice of 'montage' (Jürgens 1982). Although The Threepenny Lawsuit could be seen as an example of the 'culture of the case' (Schwartz 2018, p. 232), or a reflection of Brecht's 'litigation-mania' (Tretyakov 1934, p. 74), the essay's cinematic techniques made it compelling and remarkable. By staging the process through which the legal case was fabricated and reported, it represented a departure from existing methods of legal analysis. If Brecht's aim was to shift the focus from copyright doctrine to practice in order to show how the law is often caught in contradictions, what better way than laying bare the whole fabric of the case? In so doing, Brecht's essay unsettled and interrupted the legal process by placing the description of the case in the uneasy and elliptical tension between law and mass media. Rather than writing exclusively from the law report, the essay reconstructed the litigation as a sequence of newspaper excerpts reporting the dispute. This collection of newspaper headlines triggered several dialectical possibilities. By projecting newspaper captions of the trial, the reader could see through the case and how the public's opinion was formed. In so doing, Brecht zoomed out from the legal record while rearranging the juridical key back and forth, thus pushing the copyright paradoxes into the foreground. This rearrangement enabled the essay to chart how several assumptions about copyright were already embedded in popular knowledge. By grasping the 'outside' of copyright litigation-that is, how the press 
reported it-we can gain an insight into the 'inside'. Although the collection of newspaper clippings might be reminiscent of John Heartfield's aesthetic and political collages, and, as Schwartz has shown, could evoke a practice typical of the time, it is possible to consider the practice as one of the ways in which Brecht appeared to have been drawn to the potential of the new cinematic medium (Schwartz 2018, p. 230). In other words, the essay proceeded as a camera, with the capacity to isolate the way in which the press reported the case. Such a process acquired the movement characteristic of a montage by accumulating these punctuated headlines. The point of bringing these fragments together in a sequence was to 'double' the legal record and to elucidate its functioning. It was also a way in which Brecht attempted to show the 'public situation' as it unfolded (Brecht 2000a, p. 196). This not only materially translated the unfolding of the legal process; it also elucidated a few evident contradictions of legal expectations embodied in the press. The strength of the undertaking lay in the isolation of quotes and headlines about the controversy and the introduction of a commentary by Brecht. By introducing the device of reading the newspaper report on the legal dispute, one can see how Brecht considered the exposé of tensions and contradictions to be an effective method. While this move became an active element in illustrating the making of the case, its most significant effect was its capacity to shift from what was observed to how it was observed. In a sense, the technique was an example of Brecht's shift to second-order observation as a way of enabling the reader to form his or her own understanding of the case.

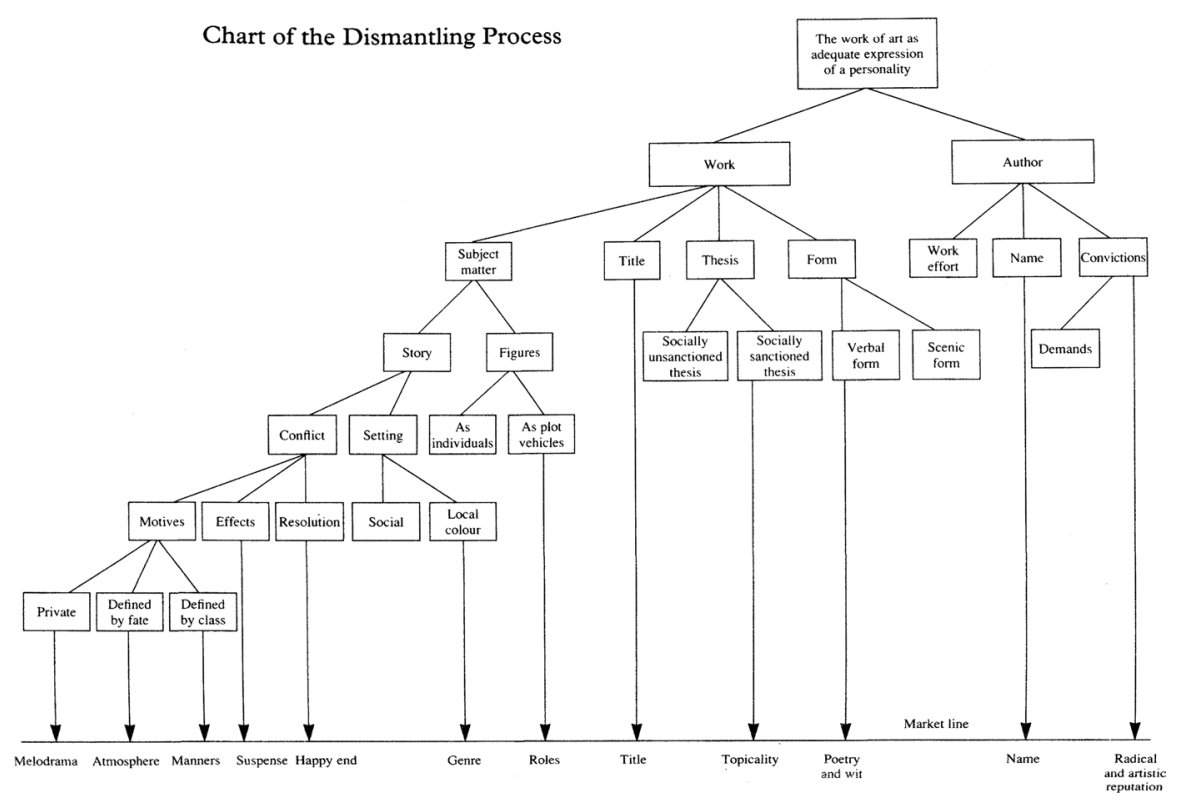

Fig. 1 Chart of the Dismantling Process' from Brecht's The Threepenny Lawsuit in Silberman (2000, p. 178) 
Yet, the central organising element of The Threepenny Lawsuit was a diagram (Fig. 1) which Brecht drew and inserted into the middle of the essay. Although Brecht was instinctively a speculative thinker, here we can see an example of a more systematic approach to theorising practice that he began to develop in the 1930s (Morley 1977, p. 90). This specific device aimed to dismantle what could be conceived as the 'montage' of copyright law (Brecht 2000a, p. 178). As an instrument of visualisation, the drawing helped to display the constitutive features of the copyright edifice ('authorship' and 'work') and show how they were transformed by the production and circulation of cultural commodities. In other words, the diagram revealed the 'functioning' parts of copyright and their mutual relations, stripped of the prevailing copyright rhetoric. Multiple arrows between these parts mapped the linkages between law and cultural production. In so doing, they traced transitions whereby legal categories were brought into what Brecht termed the 'market line' (Brecht 2000a, p. 178). This bottom-line turned out to be a place in which legal categories acquired a different configuration. For instance, the author became a 'name', the work a 'title' and the subject matter a 'genre'. Interestingly, Brecht noted that the diagram could be read 'from above' or 'from below' since what it traced was an apparatus. The diagram is also a useful point of departure for considering some of the elements noted by Brad Sherman as missing in copyright theory, that is, 'the variety of practices which help constitute the copyright work as an entity' (Sherman 1995, p. 46). By connecting the categories upon which the law was predicated, the diagram rendered visible 'the disintegration of the literary product, of the unity of the creator and work' (Brecht 2000a). The dismissal of Brecht's case, and hence the diagram, unveiled an apparatus in which 'the work [could] be given a new or several authors (who are personalities) without eliminating the original author for the purpose of market exploitation' (Brecht 2000a, p. 177).

A few months after the trial, Brecht got involved in another film production: Kuhle Wampe oder Wem gehört die Welt? (Kuhle Wampe or Who Owns the World?). It is not a coincidence that this initiative took place after his failed experience with a commercial film company. Whereas the title already appears to allude to a global capitalist dream underpinning the film industry and its commodities, the most interesting feature is that the new venture revealed a shift in approach to the legal relations embedded in the making of a film. Kuhle Wampe was the product of a collective that attempted to develop protocols and methods to change the ways in which the film industry managed authorship and ownership issues. As the link between copyright and contract was often used as a means of pre-empting the author's right to control the content of the film production, the making of Kuhle Wampe tried to circumvent this capture by bringing a lawyer into the collective and writing specific film contracts that preserved the collective character of the film's production (Pettifer 1974). Although Brecht did not go into details about how these agreements were drafted, he noted that the collective 'insisted on a contract by which we, the makers, became the authors in the legal sense, for the first time in film history or so we were told. This cost us our right to the usual guaranteed payment, but it gained us otherwise unattainable freedoms in the work' ('Collective Presentation (1932)' 1974, pp. 43-44). The important difference, then, between this film project and the preceding one was not just the question of securing copyright, but also the way in which ownership was 
prioritised before authorship. In fact, the transformation of the author into producer, the shift from authorship to ownership was precisely the way to make a difference, the strategy to concentrate power over the means of production. While this set-up facilitated the making of Kuhle Wampe, it also resonated with Walter Benjamin's theoretical insight a few years later into 'The Author as Producer'. Benjamin suggested that the question we should be asking concerned the function of a work within the literary production relations of its time. In other words, the author no longer had absolute primacy; it was the collective way of working that took over (Benjamin 1998, p. 87).

\section{Conclusion}

Brecht's brief intervention in the courtroom was subject to controversy. One of the strategies of the film company's lawyers was to focus on what they considered a weak point in Brecht's case: his well-known disregard for copyright (Gröschner and Hippe 2018). Their aim was to discredit him by pursuing a predictable argumentative route: portraying the claimant as someone whose case did not deserve an answer. At one point in the proceedings, when Brecht was on the witness stand, the film company's lawyer asked by what right Brecht was laying a claim if he did not believe in such a right. Depicting Brecht as a questionable figure in relation to copyright might have been a successful forensic technique in the context of that dispute but, however, it also enabled Brecht to confront and exploit such a low opening blow. When the lawyer addressed him about his publicly acknowledged dismissive position regarding copyright as a property right for authors, his answer was that his claim was connected to an understanding of the claim as a property of the spectator (Eisner 1973, p. 345). Although this moment is often treated as a mere anecdote of the trial and was quickly disregarded, Brecht's response can be understood in retrospect as an effective and immediate counterpunch, 'very significant as to Brecht's attitude towards his audiences' (Eisner 1973, p. 344). Precisely because it was an inappropriate gesture, the point was both suggestive and instructive. For Brecht was fascinated with problems, not solutions; with legal cases, not decisions.

It is clear today that spectators, readers and audiences were for too long sidelined in copyright scholarship, and that they have often been construed in law as being passive recipients of the commodity. Looking at the way in which copyright has silenced such a dimension might in itself lead us to imagine the history of copyright differently. Would it be possible to think about copyright by turning it around, by looking at the modes of engagement, the relations and connections it has produced? Would that history be able to trace how spectators, readers, audiences were in fact effects and constructions of these properties? And, if so, would that history be capable of distinguishing and indexing the changes entailed in moving from passive modes of reception to active social engagement? Interestingly some of those questions might also be rooted to the ways in which Brecht attempted to develop theatre and film practices to sharpen the spectator's critical mind.

With the advent of the internet, copyright law has recently re-imagined its boundaries by becoming particularly attentive to 'communication to the public' as a 'new' right. The issue here is whether copyright had not always been the consequence of a 
history of technology affecting and channelling that right under different guises. In other words, was it not so much redundant or tautological as perhaps legally necessary to recognise such a right in order to avoid marginalisation? It would be hard to imagine how Brecht would have responded today to copyright, a law even more loaded with contradictions after the digital revolution. On the one hand, its expansion in the late twentieth and twenty-first centuries is evident and criticisable; we might argue that Brecht anticipated our current shift from distribution to communication. On the other hand, more possibilities for the exposure of legal contradictions have emerged after the rise of the computer. It is easy to trace how media convergence and digitisation have pushed for the recognition of new rights and simultaneously developed anti-circumvention measures. Similarly, it seems clear that the rise of open source might be seen not just as an obvious alternative to copyright, but also as a development of contemporary capitalist practices predicated on participation. Although some scholars have seen in The Threepenny Lawsuit a precursor to the open source movement, such celebratory genealogy obscures the fact that copyright appears in Brecht's essay as a contingent experiment. Brecht used the litigation as a test to stage copyright's contradictions rather than simply criticising it as a property device to claim rights. Brecht moved beyond and underneath the fictions governing copyright—namely 'authorship', 'ownership' and 'work' - in order to expose their contribution to the production lines of commodities in the marketplace. Of course, Brecht dismissed the very notion of copyright and its identity as a property right of the author. But this could miss the fact that Brecht's attitude was broadly characterised by an attempt to challenge consensus (Frisch 1948, p. 106). Therefore, it is easy to imagine Brecht casting a disbelieving eye on advocates of the emancipatory potential of the open source movement in a post-commodity world.

Acknowledgements Thanks to Brent Salter, Derek Miller and the participants in 'Copyright and Collaboration in Theater' (Yale 2018) for their helpful comments and questions. Special thanks to Anton Schütz and the two anonymous reviewers for their suggestions.

Open Access This article is licensed under a Creative Commons Attribution 4.0 International License, which permits use, sharing, adaptation, distribution and reproduction in any medium or format, as long as you give appropriate credit to the original author(s) and the source, provide a link to the Creative Commons licence, and indicate if changes were made. The images or other third party material in this article are included in the article's Creative Commons licence, unless indicated otherwise in a credit line to the material. If material is not included in the article's Creative Commons licence and your intended use is not permitted by statutory regulation or exceeds the permitted use, you will need to obtain permission directly from the copyright holder. To view a copy of this licence, visit http://creativecommons.org/licen ses/by/4.0/.

\section{References}

Alexander, Isabella, and Tomás Gómez-Arostegui. 2016. Research handbook on the history of copyright Law. London: Edward Elgar.

Benjamin, Walter. 1935. The work of art in the age of mechanical technological reproducibility. 1st version, Grey Room, No. 39, (Spring 2010), pp. 11-38.

Benjamin, Walter. 1936 [1970]. The author as producer. New Left Review 1(62): 83-96.

Benjamin, Walter. 1998. Understanding Brecht. London: Verso. 
Brecht, Bertolt. 1964a. The film, the novel and epic theatre (from the Threepenny Lawsuit). In Brecht on theatre, ed. J. Willett. New York: Hill and Wang.

Brecht, Bertolt. 1964b. Sur le système cinématographique. Cahiers du Cinéma 114: 14-20.

Brecht, Bertolt. 1970. Sur le cinema. Paris: Editions l'Arche.

Brecht, Bertolt. 1977. Against Georg Lukács. In Aesthetics and politics, ed. F. Jameson, 68-85. London: Verso.

Brecht, Bertolt. 2000a. The Threepenny material (1930-1932). In Bertolt Brecht on film and radio. London: Methuen.

Brecht, Bertolt. 2000b. The Kuhle Wampe film (1932). In Bertolt Brecht on film and radio. London: Methuen.

Brewster, Ben. 1975. Brecht and the film industry (on The Threepenny Opera film and Hangmen Also Die). Screen 16(4): 16-33.

Bowrey, Kathy. 1996. Who's writing copyright history? European Intellectual Property Review 18(6): 322-329.

Buccafusco, Christopher, and Paul Heald. 2013. Do bad things happen when works enter the public domain: Empirical tests of copyright term extension. Berkeley Technology Law Journal 28(1): 1-43.

'Collective Presentation (1932)'. 1974. Screen 15(2): 43-44.

Deazley, Ronan, Martin Kretschmer, and Lionel Bently. 2010. Privilege and property. Essays on the history of copyright. Cambridge: OpenBook.

Dommann, Monika. 2015. Mehr Brecht als Recht - Der Dreigroschenprozess als Gerichtsbühne. e.t.ü. HistorikerInnen-Zeitschrift: 28-31.

Edelman, Bernard. 1973. Le Droit saisi par la photographie. Paris: F. Maspero. [1979. Ownership of the Image. Elements for a Marxist theory of law, trans. Elizabeth Kingdom. London: Routledge and Kegan Paul].

Eisner, Lotte. 1973. The haunted screen. Expressionism in the German cinema and the influence of Max Reinhardt. Berkeley: University of California Press.

Elsaesser, Thomas. 1990. Transparent duplicities: Pabst's Threepenny Opera. In The films of G.W. Pabst, ed. Eric Rentschler. New Brunswick: Rutgers University Press.

Farneth, David, Elmar Juchem, and Dave Stein. 1999. Kurt Weill: A life in pictures and documents. New York: The Overlook Press.

Frisch, Max. 1948. Diary. In Brecht. As they knew him, ed. Hubert Witt. Berlin: Seven Seas Books.

Gaines, Jane. 1991. Contested culture: The image, the voice and the law. Chapel Hill: University of North Carolina.

Gersch, Wolfgang. 1975. Film bei Brecht. Berlin: Henschelverlag.

Giles, Steve. 1997. Bertolt Brecht and critical theory: Marxism, modernity and the Threepenny Lawsuit. Berne: Peter Lang.

Giles, Steve. 1998. Marxist aesthetics and cultural modernity in Der Dreigroschenprozeß. In Bertolt Brecht: Centenary essays, ed. Steve Giles and Rodney Livingstone, 49-61. Amsterdam: Rodopi.

Glahn, Philip. 2014. Bertolt Brecht. London: Reaktion Books.

Gröschner, Annett, and Christian Hippe. 2018. Laxheit in Fragen Geistigen Eigentums. Brecht und Urheberrecht. Berlin: Verbrecher Verlag.

Jameson, Fredric. 1998. Brecht and method. London: Verso.

Jelavich, Peter. 2006. Berlin Alexanderplatz: Radio, film, and the death of Weimar culture. Berkeley: University of California Press.

Jürgens, Martin. 1982. Zum Prinzip der Montage in Bertolt Brechts 'soziologischen Experimenten'. Zeitschrift für Literaturwissenschaft und Linguistik 46(12): 88-103.

Hacking, Ian. 2002. Historical ontology. Cambridge, MA: Harvard University Press.

Heidt, Todd. 2014. Double take: Béla Balázs and the visual disorientation of G.W. Pabst's Dreigroschenoper. Seminar: A Journal of Germanic Studies 50(2): 178-196.

Hinton, Stephen. 1990. Kurt Weill: The threepenny opera. Cambridge: Cambridge University Press.

Kaplan, Benjamin. 1967. An unhurried view of copyright. New York: Columbia University Press.

Katz, Pamela. 2015. The partnership: Brecht, Weill, three women, and Germany on the brink. New York: Anchor Books.

Kracauer, Siegfried. 1932. Ein soziologisches Experiment? Zu Bert Brechts Versuch Der Dreigroschenprozeß. Frankfurter Zeitung. 28 February 1932.

Kracauer, Siegfried. 1947. From Caligari to Hitler. A psychological history of German cinema. Princeton, NJ: Princeton University Press. 
Kretschmer, Martin, Ronan Deazley, and Lionel Bently. 2013. The history of copyright history (revisited). World Intellectual Property Organization Journal 5(1): 35-44.

Kuhn, Tom, and Steve Giles. 2003. Brecht on art and politics. London: Methuen.

Lellis, George. 1982. Bertolt Brecht, Cahiers du Cinéma and contemporary film theory. Ann Arbor: UMI Research Press.

Lukács, György. 1923. History and class consciousness [History and class consciousness: Studies in Marxist Dialectics]. Cambridge, MA: The MIT Press.

Markus, Gyorgy. 2001. Walter Benjamin or: The commodity as phantasmagoria. New German Critique 83: $3-42$.

Morley, Michael. 1977. Brecht: A study. London: Rowman and Littlefield.

Morley, Michael. 1998. Book review: Steve Giles' 'Bertolt Brecht and critical theory: Marxism, modernity and the Threepenny Lawsuit. Kurt Weill Newsletter 16(1): 14.

Mueller, Roswitha. 1986. Brecht and communications. Communications from the International Brecht Society 16(1): 18-23.

Mueller, Roswitha. 1987. Montage in Brecht. Theatre Journal 39(4): 473-486.

Mueller, Roswitha. 1989. Brecht and the theory of media. London: University of Nebraska Press.

Mussawir, Edward. 2005. The cinematics of jurisprudence. Law and Literature 17(1): 131-152.

Parker, Stephen. 2014. Bertolt Brecht: A literary life. London: Bloomsbury.

Patterson, Lyman Ray. 1968. Copyright in historical perspective. Nashville: Vanderbilt University.

Petrie, Graham. 2004. Berthold Brecht and Béla Balázs: Paradoxes of exile. Canadian Journal of Film Studies 13(1): 2-27.

Pettifer, James. 1974. Against the stream-Kuhle Wampe. Screen 15(2): 49-64.

Philpotts, Matthew. 2004. Brecht and the institution(s) of literature. In The modern restoration: Re-thinking German literary history, ed. Stephen R. Parker, Peter J. Davies, and Matthew Philpotts, 19301960. Berlin: Walter de Gruyter.

Rayns, Tony. 2007. The Threepenny Opera: Doubles and duplicities. The Criterion Collection. 18 September 2007. https://www.criterion.com/current/posts/614-the-threepenny-opera-doubles-and-dupli cities.

Rokem, Freddie. 2014. Materializations of the supernatural. Paragrana 23(1): 71-87.

Rose, Mark. 1988. The author as proprietor: Donaldson v. Becket and the genealogy of modern authorship. Representations 23: 51-85.

Schwartz, Frederic J. 2018. Brecht's 'Threepenny Lawsuit' and the culture of the case. Oxford Art Journal 41(2): 219-247.

Silberman, Marc (ed.). 2000. Bertolt Brecht on film and radio. London: Methuen.

Sherman, Brad. 1995. Appropriating the postmodern. Copyright and the challenge of the new. Social \& Legal Studies 4: 31-54.

Sherman, Brad. 2011. What is a copyright work? Theoretical Inquiries in Law 12(1): 99.

Sherman, Brad, and Leanne Wiseman. 2012. Introduction. In Copyright and the challenge of the new, ed. Brad Sherman and Leanne Wiseman. London: Kluwer Law International.

Symonette, Lys, and Kim H. Kowalke. 1997. Speak low (when you speak love): The letters of Kurt Weill and Lotte Lenya. Berkeley: University of California Press.

Tretyakov, Sergei. 1934. Bert Brecht. In Brecht. As they knew him, ed. Hubert Witt. Berlin: Seven Seas Books.

Towse, Ruth, and Richard Watt. 2008. Recent trends in the economics of copyright. London: Edward Elgar.

von Götz von Olenhusen, Albrecht. 2017. Das Droit Moral des Urhebers und der Film der Zwanziger Jahre. Zeitschrift für geistiges Eigentum 9: 210-232.

Willett, John. 1977. The theatre of Bertolt Brecht. London: Methuen.

Willett, John. 1984. Brecht in context: Comparative approaches. London: Methuen.

Wizisla, Erdmut. 2014. Walter Benjamin and Bertolt Brecht: The story of a friendship. New Haven: Yale University Press.

Woodmansee, Martha. 1984. The genius and the copyright: Economic and legal conditions of the emergence of the 'author'. Eighteenth-Century Studies 17: 425-448.

Publisher's Note Springer Nature remains neutral with regard to jurisdictional claims in published maps and institutional affiliations. 